\title{
Does Innovation (Patents and R\&D) Affect Firm Value?
}

\author{
$1^{\text {st Anjelina }}$ \\ Accounting Department \\ Batam State Polytechnic \\ Batam, Indonesia \\ anjelina@polibatam.ac.id
}

\author{
$2^{\text {nd }}$ Zaenal Fanani \\ Accounting Department \\ Airlangga University \\ Surabaya, Indonesia \\ fanani@feb.unair.ac.id
}

\author{
$3^{\text {rd Ria Anggraini }}$ \\ Accounting Department \\ Illinois State University \\ Illinois, United States \\ ranggra@ilstu.edu
}

\begin{abstract}
Innovation is a risky activity because it requires a very high cost, takes a long time, and a higher failure rate. This study aims to examine the effect of innovation on firm value. This study uses a sample of manufacturing companies listed on the Indonesia Stock Exchange (IDX) in 2007-2017, a total sample of 133 companies with 1025 observations. The analysis technique used is panel data regression analysis with the STATA program 13. Innovation is measured using two proxies, (1) the number of patents and the $R \& D$ ratio to sales, and (2) firm value measured by Tobins $Q$. The results of this study are that innovation has a significant positive effect on firm value. This result supports the signal theory which states that innovation is a positive signal for the company because innovation reflects the company's competitiveness, so it will increase the value of the company.
\end{abstract}

Keywords-innovation, R\&D, patents, firm value.

\section{INTRODUCTION}

Innovation makes a country or company more productive and competitive. Innovation is also one of the factors that drives a country's economic growth. According to the 2018 Global Innovation Index, Indonesia ranks 85th of 126 countries and ranks 14th under the Philippines and Brunei Darussalam, at the SEAO level (South East Asia, East Asia, and Oceana). The Global Innovation Index (GII) is a project that continues to grow in making measurements of innovation. GII depends on two sub-indices, there are the innovation sub-input index and the innovation sub-output index. One of the pillars in the sub-input of innovation, is a human resources and research measured from education and research and development, while one of the pillars found in the innovation sub-output is the creative output measured from intangible assets. According to the Indonesian Minister of Research and Technology, Mohamad Nasir, the low competitiveness of innovation will make Indonesian technology products increasingly difficult for businesses and industries to accept, therefore to improve innovation companies must encourage investment in the field of research and development and patenting these products.

Patent rights are one measure of a country's progress. According to Delianis (2018), one of the biotechnology experts who is known to have a number of patents and brands in a seminar on drafting a patent for lecturers at the University of Bangka Belitung stated that a country's wealth and economic resilience rests with patents or HAKI owned by citizens, academics, artists, and industrialists of the country. Delianis also emphasized that the current rotation of the world economy, especially for the future, is controlled by intangible assets. This is in line with the statement of the
Director of the Yogyakarta Community Study Center (PSM), Ade Irawan (2017) that countries that focus on product innovation will be able to get out of the middle income trap and become developed countries, as evidenced by South Korea and China.

Innovation is a risky activity because it requires a very high cost, takes a long time, and a higher failure rate (Gao, Yang, \& Zhang, 2016)The high risk of this innovation activity makes the costs incurred for research and development ( $\mathrm{R} \& \mathrm{D}$ ) can be charged as a cost in tax calculation. R \& $\mathrm{D}$ expenditure is positively related to uncertainty about the future benefits of the investment (Kothari, Laguerre, \& Leone, 2002)

Besides as an indicator of the progress of a country, innovation can also reflect the firm value Innovation and company value have a positive relationship. According to Belenzon and Patacconi (2013), several consideration factors for acquiring companies are the value of the target tangible assets and intangible assets of the company, the cost of capital, taxes, and others. But there is one very important factor in the last few years, namely intellectual property. Patents positively affect the value of the company, with the patent the company has a temporary monopoly power over the patent, so that it can be used as a bargaining power in negotiations.

Innovation can also increase firm value when viewed from diversification goals. One of the reasons companies diversify is to find a good match between existing innovation activities and business lines and generate more efficient allocation of resources. Diversification is considered as a process of increasing productivity. When diversified companies have innovations that are more applicable in the industries they enter, good compatibility like that must increase firm value (Rong and Xiao, 2017).

The motivation of this research is that several studies using innovation variables are only related to research and development $(R \& D)$ costs or other measurements besides the number of patents. For example Prihadyanti and Laksani (2015) examined R\&D and innovation in manufacturing sector companies, with innovation variables measured by the number of scores for the existence of defective product reductions, reduction in the use of raw materials and energy, etc. during 2010-2011. Whereas Nohong (2016) examined the innovation, growth, size and value of pharmaceutical companies in Indonesia. The variable of innovation is measured by the costs incurred by the company for research and development activities. 


\section{LITERATURE REVIEW AND HYPOTHESES}

Signal theory comes from the work of Nobel prize winner Michael Spence, who introduced information asymmetry into the economic model of decision-making. In the case of information asymmetry, those who have better information will "send signals" to other parties to influence their choices (Micheli and Gemser, 2016). According to Morris (2012) signal theory shows how information asymmetry can be reduced by providing more information that signals others. In signal theory, sellers on the market are initially assumed to have more information about their products than buyers. If the buyer does not have information about a specific product but has some general perceptions, the buyer will value all products at the same price which is a weighted average of their general perception.

Changing competition conditions have driven the need to determine the company's strategy by involving investment in intangible assets. This is because products must be differentiated and are the result of innovation activities (Lev and Zambon, 2003). According to Orens, Aerts, \& Lybaert (2009) intellectual capital is an asset or monetary resource without physical substance, such as innovation, knowledge, research and development, employee training or customer satisfaction that underlies the company's valuation process. Lev and Zambon (2003) also state that innovation aims to summarize the value of organizational capabilities and competencies, which represent productive factors with recognizable values and allow them to become property rights. Corporate values and intellectual capital have a positive relationship according to signal theory (Orens, Aerts, \& Lybaert, 2009). According to Guthrie and Petty (2000) companies respond to user requests to provide intellectual capital information, because annual reports are a useful source of data to provide important signals. Signal theory shows that companies are interested in giving "good news" to the market to avoid low stock valuations (Inchausti, 2010). One positive signal from the company is information about company innovation because it signals a company's competitive ability (Sood and Tellis, 2009).

\section{A. Previous Research}

Innovation affects firm value (Nohong, 2016; Rubera and Kirca, 2017). Rubera and Kirca (2017) examine the relationship of innovation, customer satisfaction, and company value. The researcher stated that creating value for customers and shareholders is not two different goals. Innovation can create value for shareholders through customer satisfaction. The results of this study are (1) customer satisfaction is a mediation of the relationship of innovation and company value, besides that innovation has a direct positive impact; (2) the influence of innovation on customer satisfaction is stronger for companies that carry out house-of-brand strategies, which dominate the market, and operate in less competitive industries; (3) The effect of innovation on corporate value is stronger for companies that follow corporate branding strategies, which do not dominate their markets, and which operate in competitive industries. The results of the Nohong (2016) study, namely the innovation of pharmaceutical companies in Indonesia were able to increase company value, company size and company growth. This is inversely proportional to the results of Balasubramanian and Lee (2008) 's research which shows that company size is negatively related to the quality of innovation.

Research related to innovation in Indonesia conducted by Prihadyanti and Laksani (2015) which examines the R \& D and innovation in the manufacturing sector company in Indonesia. One of the backgrounds of this research is to answer the debate over the existence of R \& D as a driving factor for the creation of innovation. The research sample was 189 companies in the manufacturing industry sector in Jabodetabek. The results of this study are (1) there are differences in the existence of innovations between companies that do R \& D and those that do not do R \& D; (2) the influence of $R \& D$ activities on the level of innovation of companies in Indonesia's manufacturing sector. The level of R\&D expenditure also affects the existence of innovation. The results of this study also answer the debate on innovation without R\&D theory, which states that there is no significant difference between companies that do R\&D and companies that do not do $R \& D$ in generating innovation

Rosenbusch, Brinckmann, and Bausch (2011) examine whether innovation always benefits especially for smaller and scarce companies with resources. This study uses a meta approach to analyze the relationship between innovation and the performance of Small Medium Enterprise (UKM). The findings of this study, both innovation orientation and innovation activities create value for new SMEs and established SMEs. In general, SMEs that pursue innovation strategies have sufficient resources and capabilities to benefit from innovation. Although innovation implies high initial investment, sustainable investment, risk, and uncertainty, innovation will also provide benefits such as differentiation from competitors, consumer loyalty, premium prices for innovative products, and barriers to entry for potential imitators are generally greater than the costs.

\section{B. Innovation and Firm Value}

Innovative companies get high stock returns (Ronald and Tom, 1999). Companies that do more innovation will lead to better firm values (Bayus, Erickson, \& Jacobson, 2003). The ultimate goal of R\&D is the evolution, strengthening, and expansion of the company's core capabilities, which form the foundation for developing new businesses (Ikoma, 2006). New products introduced from innovative companies will increase sales. This is in line with (Artz, Norman, Hatfield, \& Cardinal, 2010) that a company's ability to produce sustainable innovations is more important in order to increase profitability or company value.

Ikoma (2006) defines innovation as the activity of creating new products (goods or services) using new technology, new ideas, or new processes, generating profits from marketed products, and increasing economic value. Companies can master the market by expanding the company's core capabilities or creating new core enterprise capabilities. When companies develop new business models companies also have to invest in $\mathrm{R} \& \mathrm{D}$, in order to increase company value. According to Srinivasan, Pauwels, SilvaRisso, and Hanssens (2009) investors react positively through stock returns to companies that launch innovations. Commercialization activities such as innovation, positively affect the rate of return, because it is a signal of the company's competitive ability and expansion of the company's products (Sood and Tellis, 2009). Thus, based on the theory of innovation signals is a positive signal for 
companies that innovate because it is a signal of the company's competitive ability. Companies that innovate will also increase company value because innovation has a competitive advantage (Artz, Norman, Hatfield, \& Cardinal, 2010). Sorescu and Spanjol (2008) found that innovation was associated with an increase in corporate profits. A company that innovates will maintain a high performance position and have profits above its competitors (Roberts, 1999).

H1: The higher the company's innovation, the higher the value of the company.

\section{Methodologi}

\section{A. Data}

The research data was derived from the annual financial statements of companies listed on the Stock Exchange 20072017 period and patent data companies listed on the website of the Directorate General of Intellectual Property of the Ministry of Justice and Human Rights of the Republic of Indonesia (DGIP) in the period 2007-2017. The sampling technique used was nonprobability sampling by purposive sampling, namely the technique of determining the sample with certain considerations (Sugiyono, 2018). The sampling criteria in this study are:

1) Manufacturing companies listed on the Stock Exchange for the period 2007-2017.

2) Companies that do not have a positive tax burden in the income statement.

3) Companies that do not have negative profit before tax.

Based on the criteria for the sample selection process, the number of observation samples of this study were 133 manufacturing companies listed on the Indonesia Stock Exchange from 2007 to 2017, so that the total observation in this study was 1205 company financial statements.

\section{B. Variable}

The definitive operational explanation and measurement of all variables used in the research hypothesis are as follows:

1) Innovation is an idea, practice, or object that is considered new by an individual or other adoption unit (Rogers, 1971). Innovation in this study was measured using two proxies, namely:

- The company's patent is obtained from the number of patents obtained by the company on the website of the Directorate General of Intellectual Property (DJKI).

- Research and development expenditure (R\&D) on sales (Mukherjee, Singh, \& Žaldokas, 2017).

2) Company value is the company's selling price that is considered feasible by prospective investors if the company is to be sold (Fuad, H, Nurlela, Sugiarto, \& Y.E.F, 2006). The indicator of company value is the price of shares traded on the stock exchange for companies that sell their shares to the public (Fuad, H, Nurlela, Sugiarto, \& Y.E.F, 2006). The value of the company is proxied using the Tobin's Q ratio as measured by the formula (Huang, Zhang, Deis, \& Moffitt, 2009; Toivanen, Stoneman, \& Bosworth, 2002):

$$
\text { Tobin's } Q_{i t}=\frac{\mathrm{MVE}_{\mathrm{it}}+\mathrm{BVA} \mathrm{it}_{\mathrm{it}}-\mathrm{BVE}_{\mathrm{it}}}{\mathrm{TA}_{\mathrm{it}}}
$$

Explanation:

MVE : Equity market value, calculated from the closing stock price multiplied by the number of outstanding shares (market capitalization)

BVA : book value of assets, obtained from total assets.

BVE : Book value of equity, obtained from total equity

TA : Total assets

it : for each firm i year $\mathrm{t}$

The control variables in this study are:

1) Leverage is a measurement of the proportion of debt in the capital structure and the ability of a company to repay debt (Mardianto, 2009). Leverage is measured by total debt divided by total assets, where total debt is the sum of shortterm debt and long-term debt.

$$
\text { Leverage }=\frac{\text { (Short-term deht }+ \text { T.ang-term deht) }}{\text { Total asscts }}
$$

2) Profitability is the ability of a business to generate operating profits for a certain period or measurement of a company's ability to generate profits (Mardianto, 2009). Profitability is measured by earnings before interest and tax divided by total assets (Atanassov and Liu, 2014; Mukherjee, Singh, \& Žaldokas, 2017).

$$
\text { Profitability }-\frac{\text { Eaming befcre interst ard tax }}{\text { Total assets }}
$$

3) Tangibility is tangible assets that can be seen, held, and have values that can be measured by the value of money. Tangibility is measured by the total net plant property and equipment (PPEnt) divided by total assets.

$$
\text { Tangibility }=\frac{\text { PrEn: }}{\text { lotal assets }}
$$

\section{RESULTS}

The results of descriptive statistics are used to describe the object under study through sample data or population as it is, without analyzing and making conclusions that apply to the public (Sugiyono, 2017) in this study can be seen in the following table:

TABLE I DESCRIPTIVE STATISTICS

\begin{tabular}{|c|c|c|c|}
\hline Variabel & Min. & Maks. & Avg \\
\hline Paten & 0 & 1864 & 20.29268 \\
\hline R\&D/Sales & 0 & 0.1432263 & 0.015932 \\
\hline TobinsQ & -3.569378 & 27.979 & 1.742034 \\
\hline Leverage & 0.0002158 & 6.840512 & 0.4910572 \\
\hline Profitability & -0.1526834 & 1.442114 & 0.1213377 \\
\hline Tangibility & 0.0000479 & 11.35947 & 0.3883478 \\
\hline
\end{tabular}

Patents are a proxy for innovation variables. The average patent value is 20,29268. This shows that the average manufacturing sector company listed on the Stock Exchange has patents registered in the DJKI for the period 2007-2017. The lowest patent value is 0 , meaning that the company does not have a patent. The highest patent value of 1864 is owned by PT Unilever Tbk in 2017.

$\mathrm{R} \& \mathrm{D} / \mathrm{Sales}$ is the second proxy of the innovation variable. $R \& D / S a l e s$ shows the ratio of $R \& D$ expenditure to sales. The average value of $R \& D$ Sales is 0.0015932 . This 
shows that the average $\mathrm{R} \& \mathrm{D}$ cost of sales is $0.15 \%$. The lowest $\mathrm{R} \& \mathrm{D} /$ Sales value is 0 , meaning that the company has no $R \& D$ expenditure in that period. The highest $R \& D /$ Sales value of 0.1432263 is owned by PT Unilever in 2007. The amount of PT Uniliver's R \& D expenditure is in accordance with the number of patents obtained by the company.

Tobins $\mathrm{Q}$ is a proxy for the firm value variable. The higher the TobinsQ value the better the value of the company. TobinsQ average value 1.742034. The lowest TobinsQ value of -3.569378 owned by PT Trias Sentosa Tbk in 2009 and the highest TobinsQ value of 27,979 owned by PT Arwana Citramulia Tbk in 2017. The negative value in BTD shows that the market value of the company's equity is smaller than the book value assets and equity of the company.

Leverage, Profitability, and Tangibility are control variables in this study. Leverage is a measurement of a company's ability to pay debts or can be interpreted by how much a company's assets are financed by debt or part of the assets used to guarantee corporate debt calculated from total debt divided by total assets. The average value of leverage is 0.4910572 , this indicates that the average company finances assets with debt or has a share of assets to pledge a debt of $49.10 \%$. The lowest leverage value of 0,0002158 was owned by PT Betonjaya Manunggal Tbk in 2009 and the highest leverage value of 6,840512 was owned by PT Trias Santosa Tbk in 2007.

Profitability is a measurement of company profitability. Profitability average value is 0.1213377 , this shows that the average company has profit before interest and tax $12.13 \%$ of total assets. The lowest profitability value was -0.1526834 owned by PT Eterindo Wahana Tbk in 2008 and the highest value was 1.442114 owned by PT Trias Sentosa Tbk in 2009 .

Tangibility is measured by net plant property and equipment (PPEnt) divided by total assets. The average Tangibility value is 0.3883478 , this indicates that the average PPEnt of total assets is $38.83 \%$. The lowest value is 0.0000479 owned by PT Indopoly Swakarsa Industry in 2017 and the highest value is 11,35947 PT Trias Sentosa Tbk in 2009.

All research models have met the assumption of multicollinearity and heteroscedacity. The analysis model in this study uses multiple linear regression models. The following equation model is used:

$\mathrm{FV}=\alpha 1+\beta 1 \mathrm{R} \& \mathrm{D}+\beta 2 \mathrm{PATENT}+\beta 3 \mathrm{LE}+\beta 4 \mathrm{PR}+$ $\beta 5 \mathrm{TL}+\varepsilon$

Explanation:

Innovation

$=\mathrm{R} \& \mathrm{D}$ and PATENT

$\mathrm{LE} \quad=$ Leverage

PR = Profitability

TL = Tangibility

FV $\quad=$ Firm Value

$\alpha 1 \quad=$ Constants

$\beta 1, \beta 2, \beta 3, \beta 4, \beta 5=$ Regression coefficient

$\varepsilon \quad=$ Error

So, the model used to explain the analysis of the interpretation of this research model can be seen in table 2 . This research model uses the fix effect model after passing the chow test, hausman test and Lagrange Multiplier Test stages. Based on table 2, the results of the significance test of the research hypothesis show the significance value of innovation measured by patents $(0,000>0.01)$ and $R \& D$ $(0.004>0.01)$ less than the $1 \%$ significance level with a positive coefficient. These results indicate that the higher the company's innovation, the higher the value of the company, so it can be concluded the hypothesis of this research is accepted.

\begin{tabular}{|c|c|c|c|}
\hline \multirow{3}{*}{ Description } & \multirow{2}{*}{\multicolumn{3}{|c|}{$\begin{array}{c}\text { Dependent: Firm Value } \\
\text { Fixed Effect Model }\end{array}$}} \\
\hline & & & \\
\hline & $\beta$ & $\mathrm{T}$ & $p>|t|$ \\
\hline Constants & 1.425 & 14.08 & \\
\hline Patent & 0.013 & 9.94 & $0.000 * * *$ \\
\hline R\&D/Sales & 17.648 & 2.02 & $0.004 * * *$ \\
\hline Leverage & -0.449 & -1.79 & $0.074 * *$ \\
\hline Profitablity & 3.669 & 5.24 & $0.000^{* * * *}$ \\
\hline Tangibility & -0.542 & -2.38 & $0.018^{* *}$ \\
\hline $\mathrm{F}$ & & & 26.45 \\
\hline Prob $>F$ & & & $0.000^{* * *}$ \\
\hline $\mathrm{R}^{2}$ & & & 0.129 \\
\hline
\end{tabular}

The research hypothesis states that the higher the innovation, the higher the value of the company. The results of this study indicate that innovation that is proxied by the number of patents and $\mathrm{R} \& \mathrm{D}$ has a significant positive effect on firm value. The results of this study are in line with the results of the study (Bayus, Erickson, \& Jacobson, 2003; Ronald and Tom, 1999). Innovation is a positive signal for companies, because innovation reflects the company's competitiveness. Companies that innovate will increase profitability (Artz, Norman, Hatfield, \& Cardinal, 2010). A company that innovates will improve its performance in order to maintain its position so that it has profits above its competitors. The results of this study also prove that companies that innovate have a high market capitalization value and investors react positively to the company's innovation. This result can be seen based on research sample data, namely manufacturing companies in 2007-2017 which show that companies that have many patents have high tobinsQ values, for example PT Unilever which has the highest number of patents in this sample has the highest tobinsQ value starting in 2010 until 2017.

The results of this study also support signal theory related to the positive relationship of innovation and company value. Nowadays innovation is a demand of the times. Consumers need innovative products. Companies that have unique resources will have good performance and will increase company value, and innovation is the result of companies that have "unique" resources (Yuliani, 2014). This shows that innovation is a "good news" for investors or consumers, because based on the theory of innovation signals is a signal of the competitiveness of the company, having bargaining power and inhibiting the entry of imitators thus this is good news for investors to invest in companies that innovate because innovation has benefits that are greater than the costs incurred, also good news for consumers because buyers place premium value for products that have specific information including innovation or because of having product differentiation.

\section{CONCLUSION}

This study aims to examine the effect of innovation on firm value. The following conclusions obtained from the 
results of this study. There is a significant positive effect of innovation on the value of the company, so the hypothesis which states the higher the innovation of the company, the higher the value of the company is accepted. The results of this study prove that the more companies have many patents, the more increasing the value of the company, as evidenced by the high capitalization of the company.

The object of this research is only for the manufacturing sector, suggestions for further research can add sample criteria other than the manufacturing sector to be comparable.

The findings from the results of this study contribute to theory, practice and regulators. The results of this study confirm the signal theory which states that innovation is "good news" because it represents the competitiveness of the company.

\section{ACKNOWLEDGMENT}

The author thanks Zaenal Fanani as my supervisor at Airlangga University for advice in writing this script and to the Batam State Polytechnic for providing some research data that I need.

\section{REFERENCES}

[1] Artz, K. W., Norman, P. M., Hatfield, D. E., \& Cardinal, L. B. (2010). A Longitudinal Study of the Impact of R\&D, Patents, and Product Innovation on Firm Performance. Journal of Product Innovation Management, 27(5), 725. doi:10.1111/j.15405885.2010.00747.x

[2] Atanassov, J., \& Liu, X. (2014). Corporate Income Taxes, Financial Constraints and Innovation. Paper presented at the NBER's Summer Institute Innovation Conference.

[3] Balasubramanian, N., \& Lee, J. (2008). Firm age and innovation. Industrial and Corporate Change, 17(5), 1019-1047. doi:10.1093/icc/dtn028

[4] Basuki. (2018). Hak Paten dan Kekayaan Intelektual Tolok Ukur Kemajuan Bangsa. Retrieved from http://ubb.ac.id/2018/03/19/hakpaten-dan-kekayaan-intelektual-tolok-ukur-kemajuan-bangsa

[5] Bayus, B. L., Erickson, G., \& Jacobson, R. (2003). The Financial Rewards of New Product Introductions in the Personal Computer Industry. Management Science, 49(2), 197-210. doi:10.1287/mnsc.49.2.197.12741

[6] Belenzon, S., \& Patacconi, A. (2013). Innovation and firm value: An investigation of the changing role of patents, 1985-2007. Research

[7] Fuad, M., H, C., Nurlela, Sugiarto, \& Y.E.F, P. 2006. Pengantar Bisnis. Jakarta: Gramedia Pustaka Utama.

[8] Gao, L., Yang, L. L., \& Zhang, J. H. (2016). Corporate patents, R\&D success, and tax avoidance. Review of Quantitative Finance and Accounting, 47(4), 1063-1096. doi:http://dx.doi.org/10.1007/s11156015-0531-3

[9] Guthrie, J., \& Petty, R. (2000). Intellectual Capital: Australian Annual Reporting Practices. Journal of Intellectual Capital, 1(3).

[10] Huang, Zhang, Y., Deis, D. R., \& Moffitt, J. S. (2009). Do artificial income smoothing and real income smoothing contribute to firm value equivalently? Journal of Banking and Finance, 33(2), 224-233. doi:10.1016/j.jbankfin.2008.07.012

[11] Ikoma, T. (2006). Research and Development and Innovation Boost Firm Value: The Goal of Technology Management Is Maximizing Firm Value. Japanese Economy, 33(4), 110-127. doi:10.2753/JES1097-203X330406

[12] Inchausti, A. G. (2010). The Influence of Company Characteristic and Accounting Regulation on Information Disclosed by Spanish Firms. European Accounting Review, 6(1)

[13] Kothari, S. P., Laguerre, T. E., \& Leone, A. J. (2002). Capitalization versus Expensing: Evidence on the Uncertainty of Future Earnings from Capital Expenditures versus R\&D Outlays. Review of Accounting Studies, 7(4), 355-382. doi:10.1023/A:1020764227390

[14] Lev, B., \& Zambon, S. (2003). Intangibles and Intellectual Capital: an Introduction to a Special Issue. Europian Accounting Review, 12(4).
[15] Mardianto, H. 2009. Intisari Manajemen Keuangan. Jakarta: Grasindo.

[16] Micheli, P., \& Gemser, G. (2016). Signalling Strategies for Innovative Design: A Study on Design Tradition and Expert Attention. Product Development \& Management Association.

[17] Morris, R. D. (2012). Signalling, Agency Theory and Accounting Policy Choice. Accounting and Business Research.

[18] Mukherjee, A., Singh, M., \& Žaldokas, A. (2017). Do corporate taxes hinder innovation? Journal of Financial Economics, 124(1), 195-221. doi:10.1016/j.jfineco.2017.01.004

[19] Nohong, M. (2016). Inovasi, Pertumbuhan, Ukuran, dan Nilai Perusahaan Farmasi di Indonesia. Jurnal Keuangan dan Perbankan, 20(2), 175-185.

[20] Orens, R., Aerts, W., \& Lybaert, N. (2009). Intellectual Capital Dislosure, Cost of Finance and Firm Value. Management Decision, 47(10).

[21] Prihadyanti, D., \& Laksani, C. S. (2015). R \& D dan Inovasi di Perusahaan Sektor Manufaktur Indonesia. Jurnal Manajemen Teknologi, 14(2).

[22] Roberts, P. W. (1999). Product innovation, product-market competition and persistent profitability in the U.S. pharmaceutical industry. Strategic Management Journal, 20(7), 655-670. doi:10.1002/(SICI)1097-0266(199907)20:7<655::AIDSMJ44>3.3.CO;2-G

[23] Rogers, E. M. 1971. Diffusion of Innovations. New York: The Free Press.

[24] Ronald, S. J., \& Tom, S. 1999. The Innovation Premium. Reading Mass: Perseus Books.

[25] Rong, Z., \& Xiao, S. (2017). Innovation-Related Diversification and Firm Value. European Financial Management, 23(3), 475-518. doi:10.1111/eufm.12110

[26] Rosenbusch, N., Brinckmann, J., \& Bausch, A. (2011). Is innovation always beneficial? A meta-analysis of the relationship between innovation and performance in SMEs. Journal of Business Venturing, 26(4), 441-457. doi:10.1016/j.jbusvent.2009.12.002

[27] Rubera, G., \& Kirca, A. H. (2017). You gotta serve somebody: the effects of firm innovation on customer satisfaction and firm value. Journal of the Academy of Marketing Science, 45(5), 741-761. doi:10.1007/s11747-016-0512-7

[28] Sood, A., \& Tellis, G. J. (2009). Do Innovations Really Pay Off? Total Stock Market Returns to Innovation. Marketing Science, 28(3), 442-456. doi:10.1287/mksc. 1080.0407

[29] Sorescu, A. B., \& Spanjol, J. (2008). Innovation's Effect on Firm Value and Risk: Insights from Consumer Packaged Goods. Journal of Marketing, 72(2), 114-132.

[30] Srinivasan, S., Pauwels, K., Silva-Risso, J., \& Hanssens, D. M. (2009). Product Innovations, Advertising, and Stock Returns. Journal of Marketing, 73(1), 24-43. doi:10.1509/jmkg.73.1.24

[31] Sugiyono. 2018. Metode Penelitian Kuantitatif. Bandung: Alfabeta.

[32] Toivanen, O., Stoneman, P., \& Bosworth, D. (2002). Innovation and the Market Value of UK Firms 1985-1995. Oxford Bulletin of Economic and Statistic.

[33] YK. (2017). Peringkat Indeks Inovasi Global RI Jauh Tertinggal. Retrieved from http://www.koran-jakarta.com/peringkat-indeksinovasi-global-ri-jauh-tertinggal/

[34] Yuliani. (2014). Ownership Structure, Innovation, to Firm Value With The Financing Decision as Mediation. Journal of Economics, Business, and Accountancy Ventura, 17(2). 